\title{
PEMANFAATAN MEDIA BARU UNTUK EFEKTIFITAS KOMUNIKASI PEMBELAJARAN DALAM MASA WABAH COVID 19
}

\author{
DTM. Muhammad Rezky Ananda \\ Program studi : Komunikasi dan Penyiaran Islam \\ Program Pascasarjana Fakultas Dakwah dan Komunikasi UIN Sumatera Utara \\ Jalan Williem Iskandar Pasar V Medan Estate \\ No. HP: 082163780083 \\ e-mail: kikymerahsaga@gmail.com
}

Naskah diterima tanggal 29 Oktober 2020 direvisi tanggal 25 Maret 2021 disetujui tanggal 1 April 2021

\begin{abstract}
Abstrak
Banyaknya sosial media yang bermunculan dan juga pembelajaran sekolah yang semakin berkembang mengharuskan mengikuti kemajuan teknologi yang ada, memunculkan kesempatan untuk mengoptimalkan kehadiran media baru sebagai media komunikasi, sehingga kemudian memunculkan pertanyaan. Tujuan penelitian ini untuk menjelaskan tentang bagaimana para guru sebagai pengguna media baru untuk mengefektifkan cara berkomunikasi di dalam kegiatan pembelajaran selama masa Pandemi Covid-19. Metode penelitian ini adalah penelitian deskriptif. Teknik pengumpulan data melalui observasi, wawancara. Hasil penelitian menunjukkan bahwa guru sebagai fasilitator informasi mampu membangun komunikasi daring yang efektif. Komunikasi efektif yang dimaksud adalah komunikasi yang senantiasa terjalin antara guru dan siswa sehingga nantinya dapat menimbulkan perubahan sikap atau karakter ke arah yang lebih baik bagi siswa. Ketepatan informasi menjadi kunci dalam menciptakan komunikasi yang efektif. Hal ini terjadi jika persamaan pengertian, sikap dan bahasa. Pesan atau informasi dapat diterima dan dimengerti serta dipahami sebagaimana yang dimasud oleh komunikator (guru). Pesan yang disampaikan dapat disetujui oleh komunikan siswa.
\end{abstract}

Kata-kata kunci: Covid-19; efektivitas; komunikasi; media baru; pemanfaatan.

\begin{abstract}
The large number of social media that have sprung up and also school learning that is increasingly developing requires following existing technological advances, giving rise to opportunities to optimize the presence of new media as a medium of communication, thus raising questions. The purpose of this study is to explain how teachers, as users of new media, make effective communication methods in learning activities during the Covid-19 Pandemic. This research method is descriptive research. Data collection techniques through observation, interviews. The results showed that teachers as information facilitators were able to build effective online communication. Effective communication is meant by communication that is always established between teachers and students so that later it can lead to changes in attitudes or characters for the better for students. Accuracy of information is the key to creating effective communication. This happens if the same understanding, attitude and language. Messages or information can be received and understood and understood as intended by the communicator (teacher). The message conveyed can be approved by the communicant student.
\end{abstract}

Keywords: Covid-19; effectiveness; communication; new media; utilization.

\section{Pendahuluan}

Kemajuan teknologi informasi dan komunikasi di zaman ini berita dari luar negeri begitu cepat tersampaikan, komunikasi jarak jauh dengan tatap muka pun bisa dilakukan. Tak dapat dipungkiri 
bahwa kehidupan zaman millenial telah dirasakan berbagai lapisan masyarakat. Kehadiran new media telah membawa dampak yang sangat signifikan dalam cara melakukan komunikasi. Media baru merupakan sebuah istilah untuk menggambarkan kemunculan era baru dalam berkomunikasi atau berinteraksi. Media baru yang menawarkan kepraktisan serta berbagai kemudahan semakin diminati berbagai kalangan masyarakat.

Paparan media sangat dirasakan oleh masyarakat millenial. Media dengan segala kontennya hadir menjadi bagian hidup masyarakat dunia. Zaman yang terus berkembang membuat media semakin beragam dan dibutuhkan oleh masyarakat. Awalnya komunikasi dalam media berjalan hanya searah, dalam arti penikmat media hanya bisa menikmati konten yang disajikan sumber media. Namun seiring perkembangan jaman, orang awam sebagai penikmat media tidak lagi hanya bisa menikmati konten dari media yang terpapar padanya, namun sudah bisa ikut serta mengisi konten di media tersebut.

Denis McQuail mendefinisikan new media atau media baru sebagai perangkat teknologi elektronik yang berbeda dengan penggunaan yang berbeda pula. Media elektronik baru ini mencakup beberapa sistem teknologi seperti: sistem transmisi (melalui kabel atau satelit), sistem miniaturisasi, sistem penyimpanan dan pencarian informasi, sistem penyajian gambar (dengan menggunakan kombinasi teks dan grafik secara lentur), dan sistem pengendalian (oleh komputer).

Ciri utama yang membedakan media baru dengan media lama adalah desentralisasi (pengadaan dan pemilihan berita tidak lagi sepenuhnya berada di tangan komunikator), kemampuan tinggi (pengantaran melalui kabel atau satelit mengatasi hambatan komunikasi yang disebabkan oleh pemancar siaran lainnya), komunikasi timbal balik (komunikan dapat memilih, menjawab kembali, menukar informasi dan dihubungkan dengan penerima lainnya secara langsung), kelenturan (fleksibelitas bentuk, isi dan penggunaan).

Media baru memiliki fungsi sebagai berikut:

1. Berfungsi menyajikan arus informasi yang dapat dengan mudah dan cepat diakses dimana saja dan kapan saja. Sehingga memudahkan seseorang memperoleh sesuatu yang dicari atau dibutuhkan yang biasanya harus mencari langsung dari tempat sumber informasinya.

2. Sebagai media transaksi jual beli. Kemudahan memesan produk melalui fasilitas internet ataupun menghubungi customer service.

3. Sebagai media hiburan. Contohnya: game online, jejaring sosial, streaming video, dan lain sebagainya.

4. Sebagai media komunikasi yang efisien. Penggunanya dapat berkomunikasi dengan siapapun tanpa terkendala jarak dan waktu, bahkan dapat melakukan video conference.

5. Sebagai sarana pendidikan dengan adanya e-book yang mudah dan praktis. Bagi mahasiswa dan pelajar penyampaian materi pembelajaran dapat diseragamkan, proses pembelajaran menjadi jelas dan menarik, lebih interaktif, efisiensi waktu dan tenaga, memungkinkan proses belajar bisa dilakukan dimana saja dan mengubah peran guru ke arah yang lebih positif dan produktif. 
Jurnal Komunikasi Universitas Garut: Hasil Pemikiran dan Penelitian

Vol. 7, No. 1, April 2021

Halaman 577-581

Para guru termasuk dalam pengguna media baru terbanyak. Mereka dapat mengakses internet dengan segala macam informasi yang tersedia. Dapat berkomunikasi dengan mudahnya dan bebas mengekspresikan ide kreatif mereka. Dengan banyaknya sosial media yang bermunculan dan juga pembelajaran sekolah yang semakin berkembang mengharuskan mengikuti kemajuan teknologi yang ada, memunculkan kesempatan untuk mengoptimalkan kehadiran media baru sebagai media komunikasi, sehingga kemudian memunculkan pertanyaan. Bagaimana para guru sebagai pengguna media baru untuk mengefektifkan cara berkomunikasi di dalam kegiatan pembelajaran selama masa Pandemi Covid-19.

Tabel 1

\begin{tabular}{cc}
\multicolumn{2}{c}{ Macam Media Baru } \\
\hline No. & Media Baru \\
\hline 1. & Komputer \\
2. & Handphone atau Smartphone \\
3. & Internet \\
4. & Sosial Network \\
\hline
\end{tabular}

\section{Metode Penelitian}

Metode yang digunakan dalam paper ini adalah metode deskriftif. Metode deskriptif dapat diartikan sebagai prosedur pemecahan masalah yang diselidiki dengan menggambarkan keadaan subjek atau objek dalam penelitian dapat berupa orang, lembaga, masyarakat dan yang lainnya yang pada saat sekarang berdasarkan fakta-fakta yang tampak atau apa adanya. Tujuan dari penelitian deskriptif ini adalah untuk membuat deskripsi, gambaran, atau lukisan secara sistematis, faktual dan akurat mengenai fakta-fakta, sifat-sifat serta hubungan antarfenomena yang diselidiki. Dapat dikatakan bahwa penelitian deskriptif merupakan penelitian yang berusaha mendeskripsikan suatu gejala, peristiwa yang terjadi pada saat sekarang atau masalah aktual.

\section{Hasil Penelitian dan Pembahasan}

Pandemi Covid-19 berdampak besar pada berbagai sektor, salah satunya pendidikan. Dunia pendidikan juga ikut merasakan dampaknya. Pendidik harus memastikan kegiatan belajar mengajar harus tetap berjalan dengan baik meskipun peserta didik berada di rumah. Solusinya adalah pendidik dituntut mendesain media pembelajaran sebagai inovasi dengan memanfaatkan media daring (online). Sesuai dengan Menteri Pendidikan dan Kebudayaan Republik Indonesia terkait surat edaran nomor 4 Tahun 2020 tentang pelaksanaan kebijakan pendidikan dalam masa darurat penyebaran Covid-19.

Kebijakan belajar dari rumah ini sangat merubah kebiasaan ataupun prilaku antara guru dan siswa. Bagaimana tidak, selama ini guru mengajar di kelas dalam artian mengajar di sebuah bangunan sekolah yang memiliki fungsi belajar mengajar, dengan didukung oleh sarana penunjang proses belajar mengajar. Dengan kebijakan baru ini guru harus berpikir keras bagaimana mencari pola komunikasi yang tepat agar pembelajaran dari rumah bisa dilakukan dengan efektif.

Jalan terbaik yaitu dengan melakukan atau mengupayakan proses pembelajaran berbasis dalam jaringan. Nama lainnya adalah pembelajaran daring (online). Sistem pembelajaran dilakukan melalui media baru, seperti computer/laptop dan smartphone yang terhubung dengan koneksi jaringan internet. Guru dapat melakukan komunikasi pembelajaran bersama di 
waktu yang sama menggunakan grub di media sosial seperti aplikasi zoom dan WhatsApp (WA) ataupun media lainnya sebagai media komunikasi pembelajaran. Dengan begitu, guru dapat memastikan siswa mengikuti proses pembelajaran dalam waktu bersamaan, meskipun di tempat yang berbeda. Guru pun dapat memberi tugas sesuai dengan tujuan materi yang disampaikan.

Komunikasi pembelajaran melalui media daring ini sangat membantu keberlangsungan pembelajaran di masa pandemi Covid-19. Guru dan siswa akan tetap aman berada di rumah masingmasing tanpa harus keluar rumah begitu juga proses komunikasi pembelajaran tetap berjalan dengan baik. Meski begitu, merubah pola atau kebiasaan sangat sulit. Karena perubahan komunikasi yang terjadi sangat cepat dan tidak terduga. Perubahan yang terjadi antara lain adalah :

1. Guru dan siswa sangat mengandalkan media baru.

2. Guru dan siswa harus mampu merubah gaya, strategi atau metode mengajar dan belajar.

3. Guru dan siswa harus mampu merubah gaya komunikasi selama pembelajaran daring.

Guru biasaya berkomunikasi satu atau dua arah di sekolah. Dengan cara bertatap muka secara langsung atau bahkan melakukan diskusi-diskusi secara bersama-sama. Guru akan lebih mudah memberikan pemaparan dan penjelasan suatu materi, sedangkan siswa akan lebih mudah dalam memahami dan berdiskusi langsung dengan gurunya. Dalam keadaan pandemi seperti ini, menjadi sangat sulit untuk tetap mempertahankan kebiasaan gaya komunikasi tersebut. Perlu adanya perubahan gaya komunikasi pembelajaran selama pandemi Covid-19. Komunikasi yang digunakan tentu bersifat jarak jauh yang dikenal sebagai komunikasi daring. Tujuan komunikasi secara daring ialah bisa diendalikan secara jara jauh, efisien waktu sehingga bisa dilakukan kapan saja dan dimana saja. Sangat mendukung kebijakan pemerintah dalam menanggulangi penyebaran Covid-19.

Komunikasi daring yang dilakukan terbagi menjadi dua. Pertama, komunikasi daring sinkron (bersamaan) ialah komunikator dengan jaringan internet yang terjadi secara bersamaan dan waktu yang nyata. Contohnya, video chat (whastapp, aplikasi zoom, dll). Kedua, jenis komunikasi daring asinkron ialah komunikasi dengan jaringan internet namun dilakukan secara tunda atau tidak bersamaan. Selain hal positif tadi tentu komuniasi daring ini memiliki banyak kelemahan. Pertama, tidak mewakili emosi pemakaianya dalam hal ini guru dan siswa. Sehingga guru sangat sulit dalam memberi pemahaman kepada siswa dan guru tidak mengetahui sejauh mana tingkat pemahaman siswanya. Kedua, terdapat informasi yang tidak penting sehingga penerima pesan atau informasi akan menjadi bingung. Ketiga, sangat menyita konsentrasi karena tidak sesuai tempat dan waktu.

Guru sebagai fasilitator informasi harus mampu membangun komunikasi daring yang efektif. Komunikasi efektif yang dimaksud adalah komunikasi yang senantiasa terjalin antara guru dan siswa sehingga nantinya dapat menimbulkan perubahan sikap atau karakter ke arah yang lebih baik bagi siswa. Ketepatan informasi menjadi kunci dalam menciptakan komunikasi yang efektif. Hal ini terjadi jika persamaan pengertian, 
sikap dan bahasa. Pesan atau informasi dapat diterima dan dimengerti serta dipahami sebagaimana yang dimasud oleh komunikator (guru). Pesan yang disampaikan dapat disetujui oleh komunikan (siswa). Tidak adanya hambatan yang berarti dalam menindaklanjuti pesan atau informasi. Tiga hal tersebut adalah unsur terjadinya komunikasi yang efektif.

Untuk memenuhi unsur-unsur komunikasi efektif dalam pembelajaran daring, guru harus melakukan berbagai hal. Antara lain:

1. Membuat aturan kelas daring, yaitu waktu dan aplikasi yang digunakan.

2. Membangun suasana yang baik dalam berdiskusi dalam kelas daring. Jangan sampai siswa yang bertanya atau membutuhkan penguatan tidak dilayani.

3. Guru senantiasa tetap menggunakan ekspresi-ekspresi verbal maupun nonverbal dalam memberikan feedback, reward dan punishment.

4. Guru harus mampu menanamkan sifat respek dalam saling menolong apabila ada siswa lain yang mengalami kesulitan.

5. Guru juga harus menanamkan jiwa demokratis kepada siswa. Demokratis ditujukan dengan memberikan kebebasan saling memberikan masukan selama pembelajaran daring, saling mendengar atau mengerti dengan keadaan dan mampu memberikan solusi dari setiap masalah yang dialami dalam pembelajaran daring selama pandemi Covid-19.

\section{Kesimpulan}

Perkembangan ilmu pengetahuan dan teknologi yang sangat maju www.journal.uniga.ac.id menyebabkan zaman yang terus berkembang semakin cepat. Salah satunya berdampak pada proses pembelajaran yang berubah sesuai mengikuti zamannya. Perubahan pola pembelajaran saat ini sangat dibutuhkan dalam pembaharuan sistem konvensional yang dinilai sudah tertinggal dan tidak relevan dengan dinamika zaman saat ini. Teknologi informasi dan komunikasi dalam proses pembelajaran sangat penting yaitu sebagai sarana penghubung dalam pelaksanaan transfer ilmu pengetahuan. Pembelajaran secara tatap muka di dalam kelas merupakan model awal pembelajaran, namun saat ini dengan berkembangnya zaman mengharuskan pembelajaran menggunakan media baru agar komuniasi dalam berlajar lebih efektif. Terutama dalam masa Pandemi saat ini, yang memang sangat mengahrusan pembelajaran menggunakan media baru.

\section{Daftar Pustaka}

Ahmad Setiadi. (2016). Pemanfaatan Media Sosial Untuk Efektifitas Komunikasi, Jurnal Ilmiah

Cangara, H, Hafied. (2005). Pengantar Ilmu Komunikasi, Jakarta: Raja Grafindo Persada.

Denis McQuail, (1987). Teori Komunikasi Massa suatu pengantar, diterjemahkan oleh Agus Dharma dan Aminuddin Ram, Jakarta: Penerbit Erlangga.

Effendy, Onong Uchyjana, (2009). Komunikasi, Teori dan Praktek. Bandung: Remaja Rosdakarya.

Fajar, Marhaeni, (2009). Ilmu Komunikasi Teori \& Praktek Edisi Pertama, Yogyakarta: Graha Ilmu. Nasrullah, Rulli, (2015). Media Sosial: Persefektif Komunikasi, Budaya, 
Jurnal Komunikasi Universitas Garut: Hasil Pemikiran dan Penelitian

Vol. 7, No. 1, April 2021

Halaman 577-581

dan Sosieteknologi. Bandung:

Simbiosa Rekatama Media. 